\title{
THE ADVANCED ECONOMIC DEVELOPMENT PROCESS AND MOTIVATING SYSTEM OF INNOVATION COMPETITION
}

\begin{abstract}
The global economy destabilized by the world financial and economic crises raises the demand for the economic development model of new contents and the corresponding development strategy. This model is relevant for countries with post-transformation economies (for example, Ukraine) that by force of historical circumstances find themselves on the periphery of global economic leadership outside the effective redistribution of the results and the benefits of scientific and technological progress having lost their former technological, economic and political power. A new type of economic development should be based on an adequate theoretical model, its scientific basis and the practical verification of the ability of the country to ensure the transition to the innovatively intensive type of the economic growth. That sort of a model and its corresponding strategy focused on national peculiarities and specific of post-transformation economies is the model of the advanced economic development. The results of this study complete the theory of the economic development, promote the expansion of predictive tools and implementation of positive features of a modern economic theory, and can also be used by governments with post-transformation economies to develop the long-term strategies.
\end{abstract}

Key words: advanced economic development, theoretical model, institutions, economic policy.

\section{Introduction}

I consider that a great deal of expectations is laid on a modern economic theory by the implementation of long-term strategic goals of the world humanrelated economic system connected with the possibility of developing $a$ theoretic model of competitive economy for the less economically successful countries. Such a model should provide the opportunities not only for catching-up devel-

Oleksandra Moskalenko, PhD, Associate Professor, Doctoral student of Political Economy Department of Accounting and Economics Faculties at State Higher Educational Institution Kyiv National Economic University "Vadym Hetman", Ukraine, e-mail: alexmoskalenko@ukr.net. 
opment, but also for the advanced economic development inherent to a potential of an economic system and revealed by motivation methods.

The issue of the advanced economic development, in my opinion, is a new scientific problem that requires careful study and answers to the following questions: Are there any prerequisites for the advanced development? What is their nature, enhance conditions and the institutional mechanisms? What features create a "chance" not only to catch up, but to get ahead in the level of economic progress of the most developed countries in the world?

An advanced economic development can be considered as an arrangement of conditions for the country development at a new qualitative level - in the competition and manufacturing, the level and quality of life, foreseeing the demand structure, types and forms of meeting the demands of an innovative society, and most importantly, in human development, intellectual, creative, civic initiative.

\section{Theories and methods}

The economic development, as it, is a subject matter of a neoclassical economic theory and modern political economy.

Proto-theoretical and methodological foundations of the advanced economic development, in my opinion, can be found in scientific theories of such scholars as Joseph Schumpeter (the theory of economic development), James Buchanan (the economic theory of politics), Nikolay Kondratiev (the theory of long-term development cycles), Simon Kuznets (the theory of economic growth) ${ }^{1}$, Paul Romer ${ }^{2}$ and Robert Lucas $^{3}$ (the theory of the "new growth"), K. Perez $^{4}$ (the technical-economic paradigm), Grzegorz Kolodko (theory of "juncture" development), Jeffrey Sachs, Joseph Stiglitz (post-keynsian), John Mayer ${ }^{6}$ (the development economics), Arthur Pigou, Vilfredo Pareto, Abba Lerner, Nicholas Kaldor, John Hicks, Abram Bergson, Paul Samuelson, Kenneth Arrow

Kuznets, S. (1971): Economic Growth of Nations. Mass.: Bellknap, Cambridge

2 Romer, Paul M. (1986): “Increasing Returns and Long-Run Growth", Journal of Political Economy, Vol. 94, No. 5, 1002-1037, http://pages.stern.nyu.edu/ promer/ IncreasingReturns.pdf.

3 Lukas, R. E. (2013): Lektsii po ekkonomicheskomu rostu [Lectures on Economic Growth]; trans from English D. Shestakov, Izd-vo Instituta Gaydara, Moscow,103-107

$4 \quad$ Perez Carlota. (2011): Technologicheskie revolutsii i finansoviy capital. Dinamika puzyrey $i$ periodov portsvetaniya [Technological revolutions and financial capital. The dynamics of bubbles and periods of prosperity]; trans/ from Eng. F. V. Maevskiy, Izdatelskiy dom "Delo" RANCHiGS, Moscow

5 Kolodko, Grzegorz V. (2011): Globalizaciya, transformaciya, krizis - chto dalshe? [Globalization, Transformation, and Crisis - What's next?], Magistr, Moscow

$6 \quad$ Mayer Jerald M., Raych James E., Filipenko Anton. (2003): Osnovny problemy ekonomiky rozvytku [The main problems of development economics], Lybid, Kyiv 
(the theory of economic welfare) etc. Among the Ukrainian theoretical scientists engaged in the research of economic development problems of new contents, it is necessary to mention Anatoliy Galchinskiy, Valeriy Geyts, Andriy Hrytsenko ${ }^{7}$, Yuriy Zaitsev, Volodymyr Lipov, Volodymyr Savchuk, Viktor Tarasevich ${ }^{8}$, Lubov Fedulova and many others. The proper approach to the problem of the advanced economic development in its pure form is performed only by some Russian scientists, such as Sergey Glazyev (the anti-crisis strategy of rapid development), Alexander Buzgalin, Andrey Kolganov (the strategy of rapid development) and A. Podberiozkin (the advanced development of human capital). Taking into consideration the features of today's economic reality in comparison to the objectives of the regulatory and positive economic theory, in my opinion ${ }^{10}$ there is an objective necessity to develop a theoretical model of the advanced economic development.

\section{Results and discussions}

By the theoretical economic model I mean a set of principles on which the national economy operates, a complex of economic institutions that define the nature of an economic and social system that dominates at the expense of a highlevel economic development, as well as real mechanisms to ensure the effectiveness of institutions. That is, I use the term model as the conventional key sets of the most important principles, institutions, forms and mechanisms for the advanced economic development.

Hryntsenko A. A., Artemova T. I., Krychevska T. O. (2012): Instytut doviry v koordynatach ekonomichnogo prostoru-chasu: monografiia [Institute of confidence in coordinates of economic space-time: monograph], State Institution "Institute of Economics and Forecasting of the NAS of Ukraine", Kyiv

8 Zavgorodnyaya E. A., Tarasevich V. N. (2008): "O metodologicheskich osnovaniyach ustoychivogo raxvitiya globalnoy chelovekorazmernoy sistemy". ["On the methodological basis of research for sustainable development of the global human-system"]. Mechanism of economic regulation, No.3, Vol. 2, 206-218

9 Buzgalin A. V., Kolganov A. I.: "V poiskach budushchego Rosii: "Economika dlya cheloveka" ili Strategiya operezhayushchego razvitiya - III", 297-352, in: Buzgalin A., Krumm R. (eds.): Rosiyskie madernazacii: diagnozy $i$ prognozy ["In search of Russia's future, "Economics for the Human" or the advanced development strategy - III", in: Russian modernizations: diagnoses and forecasts]. Vol. 16, LENAND, Moscow 2011

10 Moskalenko Oleksandra (2012): "Suchasna politychna ekonomiia i meynstrim yak metodologichnyi instrumentariy ekonomichnoi polityky vyperedzhayuchogo ekonomichnogo rozvytku krainy" ["The modern political economy and mainstream as the methodological instrument of economic policy of the advanced economic development"], Herald of the National University "Law Academy of Ukraine named after Yaroslav the Wise". Series: Economics and Law, Vol. 1(8),18-19. 
Based on the principle of the reverse movement to the interpretation of theoretical knowledge in an economic theory it opens the scope for the review and reconsideration of the theory of economic development, renovation of its main provisions in the current conditions and their practical application. In this regard, one of the theories, which we see as proto-theoretical and methodological foundations of the theory (the theoretical model) of the advanced economic development, is the theory of the economic development of the world-famous Austrian scientist Joseph Schumpeter. The latter [theory] refers to the prototype of a modern evolutionary theory. In this context, ex post explanations for patterns of economic development in the world, "living at different speeds" ${ }^{11}$ it is logical for the theory of the advanced economic development to appear. The given name, I believe, determines its contents, the logic of generalization of experience, the subject areas of economic analysis, business practices and procedures, functions, and the methodological tools ${ }^{12}$ of research. That's why neo-shumpeter approach to displaying patterns of the development of economy and society, understanding the nature and character of their [Economy and Society] own transformation in the theory of the advanced economic development takes into account the qualitative change of the development goals and values of the economic being of mankind at the present stage of its existence. The theory of the advanced economic development, in turn, must pass the verification, validation of its external (the premises and conclusions, forecasts, recommendations, consistency conclusions) and internal verification (installation and analytical apparatus).

The deep meaning of the advanced economic development is seen by me as follows. The advanced economic development is an objective process, a key demand of the market economy and the modern society with a high degree of intellectualization. As a result, the advanced development needs to occur in the active position of the societies of national states in relation to the development of their economies in the conditions of changing of technological structures, increasing of international competition, redistributing of spheres of influence on the world economy, getting out of the global recession and ensuring sustainable growth prospects. The advanced economic development, therefore, has at its core the principle of anticipatory strategic planning for the continuous improvement and development of the production of national economies in terms of its qualitative transformation in accordance with the new technological mode of production. The essential mechanisms of advanced development are: innovative modernization (the constant reconstruction of existing and new equipment);

$11 \quad$ Spence, M. (2013): The Next Convergence: The Future of Economic Growth in the Multispeed World / translated from English A. Kalinin; edited by O. Filatochev, Publishing House of the Gaidar Institute, Moscow

12 Moskalenko O. M. (2012): "Vyperedzhauchyi economichnyi rozvytok u systemi strategichnych potreb svitovogo suspilstva" ["The advanced economic development in the system of strategic needs of global society"], The researchers note: collection of scientific papers, KNEU, Kyiv. Issue 14. Part 1, 41-48. 
the development and implementation of new technological processes, new highquality competitive products that are in demand in foreign markets, judging by the current and anticipated needs of the people. The tactical goal is to provide the ability for all types of industries to perform increasing demands of a consumer, as an intellectual person, in the system of humanitarian values and needs and to be able to exceed them.

The advanced economic development at the same time serves as a set of methods and mechanisms to create conditions for the development at a more rapid pace than in other countries - in the competition and industry, the level and quality of life, anticipation of the demand structure, the type and form to meet requirements of the society. The advanced development may provide a solution to the problem of formation of a new quality of development, the economic system and society at a higher level, where the prospects of development are possible only in the conditions of advancement as the institutional structure and the innovation infrastructure, consolidating knowledge of government institutions and civil society, feedback to the government, business and society. The advanced economic development is based on breakthroughs in the methodology and methods of management of the macro and micro levels, a higher level of macro-economic management. The improved methods of governing can form a new quality of relations between the state and society and business structures, the basis of which is laid through the institution of trust in the government. Among the strategic objectives of the advanced development the initial and essential precondition is the priority for human potential development. The Person ${ }^{13}$ becomes a critical element, institutional resource of the advanced economic development strategy. This type of development is aimed at minimizing the boundaries of the "limits to growth" in the pessimistic scenario development models.

In the face of increasing economic instability on a global scale it is quite clear that the evolutionary path of the development for the post-transformationaltype economies, such as Ukraine, is unacceptable, since it only enhances binding the model of a catch-up development, based on the system of neo-liberal values of national economies management. However, neo-liberalism as an ideology of governing is undergoing a crisis today, which is reflected in the modern global economic recession and its lingering nature and civilization specificities.

I believe that the key features of the advanced economic development, reflecting its incentive system, type and the nature of competition are as follows:

Feature 1. The advanced economic development is a type of development which provides a qualitative change in economic processes and phenomena, and thus the motivational system in the direction of strengthening of intangible incentives to work and human values growth. There has been an accelerated economic growth at a rate of at least $7 \%$ per year. Economic and social institutions

13 Podberezkin A. (2007): “The Human capital”, in: The Human as a factor in advanced economic development. Moscow, www.nasledie.ru, (24.11.2007) 
receive a push to advance their adaptation to the existing institutional framework. Also, there appears a qualitative substantial content of future expectations of economic agents regarding the progressive changes in the economy. These progressive changes are: the identification of advanced technologies of the future and their scientific rationale; the birth and development of future technologies within the framework of existing technological mode of production.

Feature 2. The advanced development is based on the macro-economic policy, which should provide positive economic changes. The latter provide the appearance in the national economy the optimal balance of economic agents with traditional psychology of behavior and innovators with the psychology of innovative behavior. These agents compete with each other and produce "new combinations" in the economy without diverting resources from the "old" industries. In turn, the "old" industries act as a stabilizer in time of slowdown in economic growth and give impetus to innovative industry needs through their own modernization. As a result of the need for their modernization, the "old" industries contribute to the creation of new resources in high-tech industries on the basis of the technological process of international convergence, the diffusion of innovations and their synthesis. The advanced economic development, as a process, thus contributes to the formation of the base for the emergence of advanced technologies and does not necessarily divert resources away from traditional industries but creates new resources for new industries. Thereby the advanced economic development fulfills the principle of "evolutionary expansion"14, as opposed to the principle of Schumpeterian "creative destruction."

Feature 3. Innovative competition as the main type of competition in a model of the advanced economic development contributes to the country's outrunning attainment of its international competitive advantage in a certain high-tech industry, or a combination thereof. Here a key role in the innovation competition is played by a concentration of entrepreneurial efforts of economic agents, free financial resources (the new capital), defining the industry's ability to faster the development, as well as the government initiatives to implement appropriate economic policies (the exports support, an adequate for the economy needs monetary policy) .

Feature 4. The advanced development is provided by the parallel innovative modernization of traditional sectors of the economy (the principle of back support of stabilizing economic factor), the support by the state of economic agents with the traditional ("conservative") thinking, which can act as a catalyst for economic growth post-crisis recovery in time of economic downturns in terms of instability factors in the global economy and destabilizing internal political reasons.

14 Sukharev O. S. (2012): “An evolutionary economy of J. Schumpeter and its modern development", Schumpeter's reading: Proceedings of the 2nd International Scientific and Practical Conference, Perm, 14. 
Feature 5. The financial sector in the model of advanced economic development is seen as an exogenous unit, that is prone to irrational behavior or aberrations and determines the ability of economic agents (creates positive conditions or worsens them) to innovate. The developed financial sector determines the range of financial possibilities of economic agents, as subjects of traditional and innovative sectors of the economy, to the advanced economic development. The economic subjects in the conditions of its [the range] stability make the decision to change their status, and choose the type of innovation.

Feature 6. The optimal accumulation of intellectual capital in a model of advanced economic development creates an intellectual rent as an excess profit in the economy. The condition that determines the motivational system of the advanced economic development is the following: the social value created by the human capital should not unduly exceed the value that is redistributed to a medium of human capital, because the motivation to intellectual work is lost. However, in the advanced development the economic incentives lose their permanent value, and only partially influence the extension of scientific knowledge base. An important role is played by human curiosity, which becomes non-economic force and an advanced development engine. Creativity and the desire for public recognition and, in part, the subsequent material benefits become the main human motive.

Feature 7. The economic system in a model of the advanced development is some adaptive mechanism to complicated external and internal conditions. In its framework the choice of actions by economic agents is based on primarily non-economic objectives of motivational systems. Among these goals are not achievement of maximum profit and utility maximization, but the desire for creativity, social acceptance and positive earnings. They are aimed at achieving economic success of the country, society and individuals, in the face of uncertainty, information incompleteness and innovation competition. The innovative competition in the advanced economic development model is the competition between states, economic agents and individuals in particular, which moves in the sphere of knowledge. The main instruments of influence on the innovative competition market are in the action of such mechanisms as: 1) anticipatory foresight of future advanced technologies; 2) anticipatory acquisition of competitive advantages in high-tech industries; and 3) anticipatory accumulation of intellectual capital by companies and human capital expansion by individuals.

The modern type of government should be directed not only to achieve the normative values of macroeconomic aggregates, but also, and most likely and paramount, to high-quality socio-economic indicators. That's why I have the intention to propose alternative to "narrow" identities of macroeconomics the qualitative indicators of the advanced economic development, through which it manifests itself, namely: 
1) The advance in quality and effectiveness of the national economy state management, which consists in developing an effective instrument of economic policy, allowing the economy to have a so-called "margin of safety". Its provision is possible through the introduction of economic invariants into the economic system, as well as built-in automatic institutional adjusters. These include, for example, the institution of trust, its mechanism of action in the economy and reverse mechanism for effective cooperation between government, business and society.

2) The advanced development of civil society, which forms an adequate type of social and individual consciousness, the inclusion of this consciousness in the process of the country development.

3) The advanced human capital development and the advanced inclusion of human capital in the economic development process, which will allow the national economy to move to a new, higher level of economic efficiency. The world countries economic progress which, I have a certain degree of confidence, resulted from functioning of the advanced development model, was based on talented, spontaneous macro-economic solutions. These solutions became generally accepted economic practices only time later. But, anyway, these macro management mechanisms relied on the support of the human capital development, on the advanced development of human potential. Most scientists concerned with the problems of human capital, share the idea of the special importance of its impact on the growth prospects of national economies. Either way, the investment in human capital is certainly win-win, beneficial, as it allows the country to increase the efficiency of the economic system, a measure of its performance in the near future. Especially important is the priority of education development, which is manifested through investing in training specialists for priority industries of the future, high-tech, energy saving, etc.

4) The advancement in the degree of maturity of the social institutions that create economic stability, having the correct application of their functional orientation and working in the practical tradition and in accordance with the economy needs. Social institutions such as the state power institutions, the institution of law, the private property rights institution, the institution of intellectual rent, the Public Health institution, the Institution of Education and Science, and others, are able to absorb the best forms of business practices. Such forms [of business practices] are acquired by public institutions within their own obtaining or borrowing the international experience. The civilization capacity of public institutions to preserve the best traditions and national benefits is particularly important, as well as a tendency to adaptive efficiency. 
5) The institutional capacity of the economic system to advance the emergence of negative forms (outside of the "system of rules") of deviant, irrational behavior of economic agents and public institutions. This institutional capacity is provided by the insertion into the economic system of automatic exposure adjusters, namely such as legislative measures, preventive and economic ones. Thus, in advance the conditions for the ineffectiveness of the "game" out of a system of formal rules and informal "useful" customs and traditions are created. These essential conditions are the maturity of the market infrastructure, a favorable investment climate, a sufficient level of public sector funding, etc.

6) The advanced development of the productive sectors of the future, which is reflected in the financing of these sectors, their creating in the prevailing technological mode of production today, as well as in creating the infrastructure for them, science and technology (innovation), market.

\section{Conclusions}

Taking into consideration the above mentioned I have come to the conclusion that the advanced economic development should be considered as the process and an objective phenomenon due to the number of substantial motivational, social, cultural, mental reasons, laws and regularities of the economic development of the world society. The advanced economic development as a strategic need of the world society becomes consequently an appropriate response of the countries to the global challenges where the "social growth" becomes an alternative to rising inequality. The advanced economic development is nothing else but an objective reality, a phenomenon inherent to the system of economic relations that exists in potential. Such a growth is an inevitable objective process in the conditions of the review of general civilization development goals and values of humanity, their displacement to the plane of the spiritual and the material coordinates and inducing mechanisms of self-development of the economic system. The prerequisites of the advanced development are the breakthroughs in the methodology and methods of management of the macro- and micro-levels, in technology, formulation of strategic objectives and the implementation of social projects. Such breakthroughs become possible in the conditions of activating and using the effective endogenous motivational factors for the country development and innovative competition. 


\section{Literature}

- George Mavrotas and Anthony Shorrocks (eds.): Advancing Development: Core Themes in Global Economics, PALGRAVE MACMILLAN in association with the United Nations University, World Institute for Development Economics Research, United Nations University 2007

- Buzgalin A. V., Kolganov A. I.: "V poiskach budushchego Rosii: "Economika dlya cheloveka" ili Strategiya operezhayushchego razvitiya - III”, 297-352, in: Buzgalin A., Krumm R. (eds.): Rosiyskie madernazacii: diagnozy i prognozy ["In search of Russia's future, "Economics for the Human" or the advanced development strategy - III", in: Russian modernizations: diagnoses and forecasts]. Vol. 16, LENAND, Moscow 2011

- Glazev S. Yu. (2010): Strategia operezhayushchego razvitiya Rosii v usloviyakh globalnogo krizisa: Monografiya [The strategy of advanced development of Russia in the global crisis: Monograph], "Economica", Moscow

- Hryntsenko A. A., Artemova T. I., Krychevska T. O. (2012): Instytut doviry $v$ koordynatach ekonomichnogo prostoru-chasu: monografiia [Institute of confidence in coordinates of economic space-time: monograph], State Institution "Institute of Economics and Forecasting of the NAS of Ukraine”, Kyiv

- Kolodko Grzegorz V. (2011): Globalizaciya, transformaciya, krizis chto dalshe? [Globalization, Transformation, and Crisis - What's next?], Magistr, Moscow

- Kuznets, S. (1971): Economic Growth of Nations. Mass.: Bellknap, Cambridge

- Lukas, R. E. (2013). Lektsii po ekkonomicheskomu rostu [Lectures on Economic Growth]; trans from English D. Shestakov, Izd-vo Instituta Gaydara, Moscow,103-107.

- Mayer Jerald M., Raych James E., Filipenko Anton. (2003): Osnovny problemy ekonomiky rozvytku [The main problems of development economics], Lybid, Kyiv

- Moskalenko Oleksandra (2012): "Suchasna politychna ekonomiia i meynstrim yak metodologichnyi instrumentariy ekonomichnoi polityky vyperedzhayuchogo ekonomichnogo rozvytku krainy" ["The modern political economy and mainstream as the methodological instrument of economic policy of the advanced economic development"], Herald of the National University "Law Academy of Ukraine named after Yaroslav the Wise". Series: Economics and Law. Vol. 1(8),18-29.

- Moskalenko O. M. (2012): "Vyperedzhauchyi economichnyi rozvytok u systemi strategichnych potreb svitovogo suspilstva" ["The advanced economic development in the system of strategic needs of global soci- 
ety"], The researchers note: collection of scientific papers, KNEU, Kyiv. Issue 14. Part 1, 41-48.

- Romer, Paul M. (1986): "Increasing Returns and Long-Run Growth" [Electronic resources], Journal of Political Economy. Vol. 94, no. 5, 10021037, http://pages.stern.nyu.edu/ promer/IncreasingReturns.pdf.

- Perez Carlota. (2011): Technologicheskie revolutsii i finansoviy capital. Dinamika puzyrey i periodov portsvetaniya [Technological revolutions and financial capital. The dynamics of bubbles and periods of prosperity]; trans/ from Eng. F. V. Maevskiy, Izdatelskiy dom "Delo" RANCHiGS, Moscow

- Podberezkin A. (2007): Chelovecheskiy capital kak factor operezhayushchego ekonomicheskogo razvitiya [Human capital as a factor of the advanced economic development], Moscow, www.nasledie.ru.

- Spence, M. (2013): Sleduushchaya konvergenciya: budushchee ekonomichekogo rosta $v$ mire, zhyvushchem na raznych skorostyach [The Next Convergence: the Future of Economic Growth in The Multispeed World] / trans. from English A. Kalinin; edited by O. Filatocheva, Izd-vo Instituta Gaydara, Moscow

- Sukharev O. S. (2012): "An evolutionary economy of J. Schumpeter and its modern development", Schumpeter reading: Proceedings of the $2 n d$ International Scientific and Practical Conference, Perm, 12-41

- Sukharev O. S. (2013): Medodologiya i vozmozhnosti economicheskoy nauki: Monografiya [Methodology and possibilities of economic science: Monograph], INFRA-M, Moscow

- Zavgorodnyaya E. A., Tarasevich V. N. (2008): "O metodologicheskich osnovaniyach ustoychivogo raxvitiya globalnoy chelovekorazmernoy sistemy". ["On the methodological basis of research for sustainable development of the global human-system"]. Mechanism of economic regulation, No.3, Vol. 2, 206-218

Paper received: July $8^{\text {th }}, 2013$

Approved for publication: January $31^{\text {st }}, 2014$
Rad primljen: 8. jul 2013. Odobren za štampu: 31. januar 2014. 